\title{
Cream formation in a semifermented tea
}

\author{
Yuh Chung Chao ${ }^{1}$ and Been Huang Chiang ${ }^{2 *}$ \\ ${ }^{1}$ Department of Food Nutrition, China Junior College of Medical Technology, Tainan, Taiwan, Republic of China \\ ${ }^{2}$ Graduate Institute of Food Science and Technology, National Taiwan University, Taipei, Taiwan, Republic of China
}

\begin{abstract}
The formation of cream in Paochung tea, a popular semifermented tea, which undergoes a lesser degree of enzymic oxidation during manufacture, was investigated at various extraction temperatures, extraction times, pHs and leaf/water ratios. The primary components of Paochung tea cream were catechins $(30 \%)$, caffeine $(20 \%)$ and protein $(16 \%)$. (-)-Epigallocatechin gallate and $(-)$-epicatechin gallate were the major catechins precipitated during creaming, constituting $19 \%$ and $5 \%$ of the tea cream respectively. The amount of tea cream produced and its composition were influenced by extraction temperature and $\mathrm{pH}$. The tea leaf/water ratio determined the amount of tea cream formed but did not affect the cream composition. Catechins were considered to be the key component in tea cream. They interacted with caffeine and protein to induce tea cream formation.

(C) 1999 Society of Chemical Industry
\end{abstract}

Keywords: cream; semifermented tea; Paochung tea; catechins

\section{INTRODUCTION}

It has been observed that the clarity of a tea infusion changes on cooling the hot infusion down to about $20-30^{\circ} \mathrm{C}$, and keeping it further in this temperature range or lower may cause the production of precipitates and/or suspensions which are known as 'tea cream'. The development of tea cream in such tea drinks as iced teas is considered an undesirable phenomenon, because it not only creates a fouling problem during the concentration process but also limits the application of tea in some drinks owing to its unattractive appearance. ${ }^{1-3}$ Most research related to tea cream formation has focused on black tea. ${ }^{1-5}$ Roberts ${ }^{6}$ and $S$ mith $^{1}$ reported that the main components of black tea cream were caffeine and oxidised polyphenols such as thearubigins and theaflavins. The extent of cream formation was dependent upon the amount of thearubigins in the black tea infusion. ${ }^{7}$ Non-caffeine nitrogen compounds, including protein and humic acid-like substances, ${ }^{4}$ as well as a lipid complex comprising components such as 1-triacontanol, $\alpha$-spinasterol and dihydro- $\alpha$-spinasterol, have also been identified in black tea cream. ${ }^{8}$

The factors affecting cream formation in black tea include the extraction temperature, the $\mathrm{pH}$ and the concentration of the infusion. ${ }^{1-5}$ The extraction of black tea at a temperature below $35^{\circ} \mathrm{C}$ would produce an infusion incapable of creaming. ${ }^{3}$ When the $\mathrm{pH}$ of the solvent was maintained at 4 , the maximum amount of black tea cream was formed. ${ }^{1}$

The extent of enzymic oxidation during the manufacture of tea leaves affects the composition and sensory properties of the tea infusion. However, little information is available concerning cream formation in semifermented teas, which are processed under a lesser degree of enzymic oxidation. It is important to understand the similarities and differences in cream composition and cream formation behaviour between semifermented and black tea. The objectives of this study were to investigate the composition of semifermented tea cream, the roles of tea components in the cream and the effects of the extraction conditions upon cream formation.

\section{MATERIALS AND METHODS}

\section{Tea leaves}

Paochung tea, harvested and processed in November 1992 at Tao Yuin county of northern Taiwan, was used for this study. For manufacturing this semifermented tea, fresh tea leaves (TTES12) were solar withered for $c a 20 \mathrm{~min}$ and then indoor withered for $c a$ $8 \mathrm{~h}$. After panning at $270^{\circ} \mathrm{C}$ for $6 \mathrm{~min}$, the leaves were rolled for $\mathrm{ca} 7 \mathrm{~min}$ and dried at $95^{\circ} \mathrm{C}$ for $10 \mathrm{~min}$ in an oven (primary drying). The semi-dried leaves were subjected to ball rolling and then dried again in an oven to a final moisture content of $4 \%$. The tea leaves were stored in a freezer at $-10^{\circ} \mathrm{C}$ to maintain their quality.

\section{Preparation of the tea infusion}

The tea leaves were ground and passed through a 140 mesh screen to remove fine particles before extraction. The ground leaves were extracted with distilled water

\footnotetext{
* Correspondence to: Been Huang Chiang, Graduate Institute of Food Science and Technology, National Taiwan University, Taipei, Taiwan, Republic of China

Contract/grant sponsor: Council of Agriculture, ROC; contract/grant number: 83-28-08(9)

(Received 5 January 1998; revised version received 22 March 1999; accepted 24 May 1999)
} 
with various leaf/water ratios at $90^{\circ} \mathrm{C}$ for $20 \mathrm{~min}$. The extract was filtered through a 140 mesh screen and then quickly cooled down to $30^{\circ} \mathrm{C}$ or lower with a glass condenser using water $\left(25^{\circ} \mathrm{C}\right)$ as a cooling medium and held in a $2^{\circ} \mathrm{C}$ water bath for $2 \mathrm{~h}$ to allow the development of the tea cream. The tea infusion was centrifuged at $12500 \times g$ for $30 \mathrm{~min}$ to obtain a clarified infusion.

\section{Analytical}

The constituents of the tea cream were determined by calculating the contents in the original and clarified infusions and then making a comparison. The total solids contents of the original and clarified infusions were determined by drying $20 \mathrm{ml}$ of the infusions at $90^{\circ} \mathrm{C} .{ }^{9}$ For determining the caffeine content, the sample solution was adjusted to $5-30 \mathrm{mg} \mathrm{ml}^{-1}$ of caffeine concentration with distilled water. After adding $4 \%(\mathrm{w} / \mathrm{v})$ poly(vinylpyrrolidone) (PVPP) (Sigma Co, St Louis, MO, USA) to the sample solution, the mixture was held at room temperature $\left(25^{\circ} \mathrm{C}\right)$ for $30 \mathrm{~min}$ and filtered through a Whatman No 41 filter paper to remove the polyphenols. The caffeine content of the mixture was determined by measuring its optical absorbance at $276 \mathrm{~nm}$ using pure caffeine as a standard. ${ }^{10}$

The total catechins content of the original and clarified infusions was determined using the $\mathrm{HCl}-$ vanillin method. ${ }^{11}$ The catechins content of the sample solution was adjusted to $100-500 \mathrm{mg} \mathrm{m}^{-1}$ with distilled water. After adding $5 \mathrm{ml}$ of a $4 \%$ vanillin solution and $3 \mathrm{ml}$ of concentrated $\mathrm{HCl}$ to a $1 \mathrm{ml}$ sample solution, the catechins content in the mixture was determined by measuring the optical absorbance at $500 \mathrm{~nm}$ using $(+)$-catechin (Sigma Co) as a standard. For determining the polyphenolic compounds, the tea infusion was diluted 20 times with distilled water, filtered through a $0.45 \mathrm{~mm}$ filter and analysed using HPLC. ${ }^{12}$ The HPLC system (ICI Instruments, Victoria, Australia) consisted of two pumps (LC 1100) and a variablewavelength UV detector (LC 1200). The separation was performed on an Inertsil 5 ODS-80A $(250 \mathrm{~mm} \times$ $4.6 \mathrm{~mm}$ ) column (Vercopak, Taiwan) at $40^{\circ} \mathrm{C}$. Linear gradient elution was carried out at $1 \mathrm{ml} \mathrm{min}^{-1}$ flow rate from $99 \%$ solvent A $(0.1 \%$ phosphoric acid solution containing $0.2 \%$ acetonitrile and $5 \% N, N$-dimethylformamide) and $1 \%$ solvent $\mathrm{B}$ (acetonitrile) after injection to $30 \%$ solvent $\mathrm{A}$ and $70 \%$ solvent $\mathrm{B}$ at $60 \mathrm{~min}$. The response was determined at $280 \mathrm{~nm}$. The catechins kit containing pure $(+)$-catechin, (-)-epigallocatechin ((-)-EGC), (-)-epicatechin ((-)-EC), $(-)$-epigallocatechin gallate $((-)-E G C G)$ and (-)-epicatechin gallate $((-)-E C G)$ was purchased from Nuhunakoshi Co (Tokyo, Japan). Pure gallic acid, rutin and quercetin were from Sigma Co.

For the determination of protein and pectin contents, $5 \mathrm{ml}$ of tea infusion was mixed with $25 \mathrm{ml}$ of $95 \%$ alcohol for $30 \mathrm{~min}$ and centrifuged at $3000 \times \mathrm{g}$ for $20 \mathrm{~min}$, when the precipitate was redissolved in $5 \mathrm{ml}$ of distilled water. The above procedures were repeated twice. The protein content in the precipitate was determined by the Lowry $\operatorname{method}^{13}$ using bovine serum albumin (BSA) as a standard. The pectin content was determined by the procedure proposed by Blumenkrantz and Asoboe-Hansen ${ }^{14}$ using anhydrogalacturonic acid (AGA) as a standard.

The calcium, iron, magnesium, potassium, copper and zinc contents in the original and clarified infusions were determined by atomic absorption spectrophotometry (Smith-Hieftje 8000, Thermo Jarrell Ash Co, Massachusetts, USA). Samples were diluted 10 times with deionised water to avoid creaming prior to analysis.

For the free amino acid content determination the tea infusion was diluted 20 times with distilled water and filtered through a $0.45 \mathrm{~mm}$ filter. Five millilitres of filtrate was injected into a Sep-Pak C-18 cartridge (Millipore Co, Massachusetts, USA). The last $3 \mathrm{ml}$ of the filtrate was collected and analysed with an amino acid analyser (Model 415, LKB Biochem Co, UK) equipped with an Ultrapac resin column (lithium form). Citrate buffer ( $\mathrm{pH} 2.20-6.45$ ) was used for elution at a flow rate of $50 \mathrm{mlh}^{-1}$. The absorbance of the infusion was measured at $570 \mathrm{~nm}$.

\section{Statistical analysis}

The analysis of the variance employed an SAS program for PCs (SAS Institute, Inc, Cary, NC, USA). Duncan's multiple-range test was also applied to determine whether there were significant differences between individual treatments.

\section{RESULTS AND DISCUSSION \\ Composition of Paochung tea cream}

The primary components of Paochung tea cream are illustrated in Table 1. Caffeine, catechins and protein were the three major constituents. A widely supported hypothesis is that complexation is exhibited by both caffeine-polyphenols and polyphenols-protein. Complexation of polyphenols and proteins may involve two situations. ${ }^{15}$ At low protein concentrations the polyphenol associates at more sites on the protein surface to produce a monolayer which is less hydrophilic than the protein itself, and then aggregation and precipitation ensue. When the protein concentration is high, the precipitation is caused by the cross-linking of different protein molecules by the polyphenols. In the Paochung tea infusion the catechins content $(1.46 \%)$ was 10 times the protein content $(0.14 \%)$ (Table 1$)$. This is thus closer to the former situation.

It is known that the primary intermolecular forces in the caffeine-polyphenols complexation are contributed by hydrogen bonding, apolar hydrophobic interactions and coordination with a metal ion. ${ }^{16,17}$ Mejbaum-Katzenellenbogen et al $^{18}$ demonstrated that caffeine competes effectively with proteins for polyphenolic substrates. Thus the caffeine-catechins complexation is also likely to be important in Paochung tea cream formation. 
Table 1. Comparison of selected chemical constituents of original and clarified Paochung tea infusions ${ }^{a}$

\begin{tabular}{lccl}
\hline Constituent & $\begin{array}{c}\text { Original } \\
\text { infusion } \\
(\mathrm{g} / 100 \mathrm{ml})\end{array}$ & $\begin{array}{c}\text { Clarified } \\
\text { infusion } \\
(\mathrm{g} / 100 \mathrm{ml})\end{array}$ & $\begin{array}{c}\text { Tea cream } \\
(\mathrm{g} / 100 \mathrm{~m})\end{array}$ \\
\hline Total solids & 3.81 & 3.24 & 0.57 \\
Caffeine $^{\mathrm{b}}$ & 0.38 & 0.27 & $0.11(20 \%)$ \\
Catechins $^{\mathrm{c}}$ & 1.46 & 1.29 & $0.17(30 \%)$ \\
Catechins $^{\mathrm{d}}$ & & & \\
(-)-EGC $_{(-)-E C}$ & 0.027 & 0.025 & $\mathrm{NS}$ \\
(-)-EGCG $_{(-)-E C G}$ & 0.068 & 0.067 & $\mathrm{NS}$ \\
Protein & 0.303 & 0.197 & 0.106 \\
Pectin & 0.060 & 0.031 & 0.029 \\
Total amino acids $_{\text {Theanine }}$ & 0.14 & 0.05 & $0.09(16 \%)$ \\
Asp & 0.10 & 0.09 & $0.01(2 \%)$ \\
Glu & 0.076 & 0.070 & 0.006 \\
Mineral & 0.040 & 0.037 & 0.003 \\
Ca & 0.008 & 0.007 & 0.0003 \\
Fe & 0.007 & 0.006 & 0.001 \\
Mg & & & \\
K & 7.54 & 2.56 & 4.98 \\
Cu & 5.20 & 5.14 & $\mathrm{NS}$ \\
Zn & 4.00 & 4.00 & $\mathrm{NS}$ \\
\hline
\end{tabular}

a The infusion was extracted with a $10 \%$ tea leaf/water ratio at $90^{\circ} \mathrm{C}$ for $20 \mathrm{~min}$. The clarified infusion was obtained after clarification by centrifugation. For a detailed description see Materials and Methods. Values are the averages of four determinations $(n=4)$. The composition of the tea cream was determined at significance level $p<0.05$. Numbers in parentheses represent the percentages of the constituents in tea cream ( $g / d r y$ basis).

${ }^{\mathrm{b}}$ Calculated by subtracting the value of the clarified infusion from that of the original infusion

${ }^{c}$ Data were determined using the $\mathrm{HCl}-$ vanillin method.

${ }^{d}$ Data were determined by quantification of the HPLC method.

e In ppm.

NS, No significant difference at $p<0.05$.

The most abundant group of substances in the Paochung tea infusion was catechins, which also accounted for approximately $30 \%$ of the total mass of the cream. The phenolic compounds in the original tea infusion and the decreamed tea infusion were analysed using reverse-phase HPLC (Fig 1). A comparison of changes in the peak areas of the polyphenolic constituents in the Paochung tea infusion before and after decreaming demonstrated that those compounds with hydrophobicity higher than (-)EGCG (eluted after (-)-EGCG) had a higher tendency to complex with other components and form cream (Table 2). The concentrations of galloyl esters in catechins, (-)-EGCG and (-)-ECG, were markedly diminished $(p<0.05)$ after clarification, but the non-ester forms of catechins, $(-)$-EGC, $(+)-C$ and $(-)-\mathrm{EC}$, were not significantly reduced $(p>0.05)$. The percentages of $(-)-E G C G$ and $(-)-E C G$ in the cream were $19 \%$ and $5 \%$ respectively (Table 1 ). In black tea the ester-form catechins can react with other catechins to produce theaflavins or thearubigins during the fermentation process. $^{5}$ In this study the teaflavins would elute at about $59 \mathrm{~min}$ in Fig 1, but in the full chromatogram there was no evidence of their presence. It is worth noting also that the baseline in Fig 1 shows little divergence from zero, indicating the absence of unresolved thearubigins. ${ }^{11}$ Black tea cream contains approximately $17 \%$ caffeine, $66 \%$ thearubigins and $17 \%$ theaflavins, ${ }^{1,6}$ and (-)-EGCG and (-)ECG are not the primary components. The composition of the semifermented tea cream, which does not contain thearubigins and theaflavins, is obviously different from that of the black tea cream.

The galloyl group of catechins has been identified to be an active site for binding protein through a hydrogen bond. ${ }^{20}$ Martin et $a l^{16}$ suggested that a hydrophobic interaction existed between the galloyl group of polyphenols and the six-member ring of caffeine. These interaction forces contributed by the galloyl group might account for the fact that these ester-form catechins had a much greater tendency to precipitate with protein and caffeine than did the nonester-form catechins (Table 2). However, a role for the non-ester-form catechins cannot be totally ruled out in cream formation in the Paochung tea infusion. All phenolics are able to form hydrogen bonds with caffeine and are likely to be involved in complexation and precipitation.

Millin et $a l^{21}$ showed that $7 \%$ of endogenous polysaccharides, especially polygalacturonic acid, took part in cream formation in black tea by forming loosely bound complexes with polyphenolic and proteinaceous materials. Although there is little information concerning the affinity between polyphenols and polysaccharides, the complexation of pectin and other constituents is less important in cream formation in Paochung tea, because its presence was relatively low $(2 \%)$ in the cream.

The free amino acid contents in the original and clarified infusions were significantly different $(p<0.05)$, indicating that free amino acids also participated in cream formation in Paochung tea. The major free amino acids involved in the formation of the tea cream were theanine $(39 \%)$, followed by glutamic acid (Glu) (10\%) and aspartic acid (Asp) (5\%) (Table 1). Other free amino acids to contribute to the formation of the tea cream included asparagine (Asn), tyrosine (Tyr), valine (Val), alanine (Ala), glutamine (Gln), proline (Pro) and glycine (Gly). However, Nagalakshimi and Seshadri ${ }^{4}$ did not find a significant amount of theanine in the acid hydrolysate of black tea cream and concluded that free amino acids were not involved in the formation of tea cream. Nevertheless, only approximately $8 \%$ of the total free amino acids in the infusion of Paochung tea were lost after the creaming process. Therefore we suspect that free amino acids may simply co-precipitate with insoluble complexes during cream formation.

The mineral contents of Paochung tea before and after clarification are shown in Table 1. Among the six minerals tested, calcium appeared to be the only mineral to be significantly involved $(p<0.05)$ in cream formation. About $66 \%$ of the calcium in the original 
Figure 1. High-performance liquid chromatograms of polyphenols in Paochung tea infusion (a) before and (b) after clarification: peak 2,

theobromine; peak 3 , gallic acid; peak 6 , caffeine; peak 7 ,

(-)-epigallocatechin; peak 8 ,

(+)-catechin; peak 10, (-)-epicatechin; peak $12,(-)$-epigallocatechin gallate; peak 18 , rutin; peak $19,(-)$-epicatechin gallate; peak 24 , quercetin. Other peaks are unidentified.
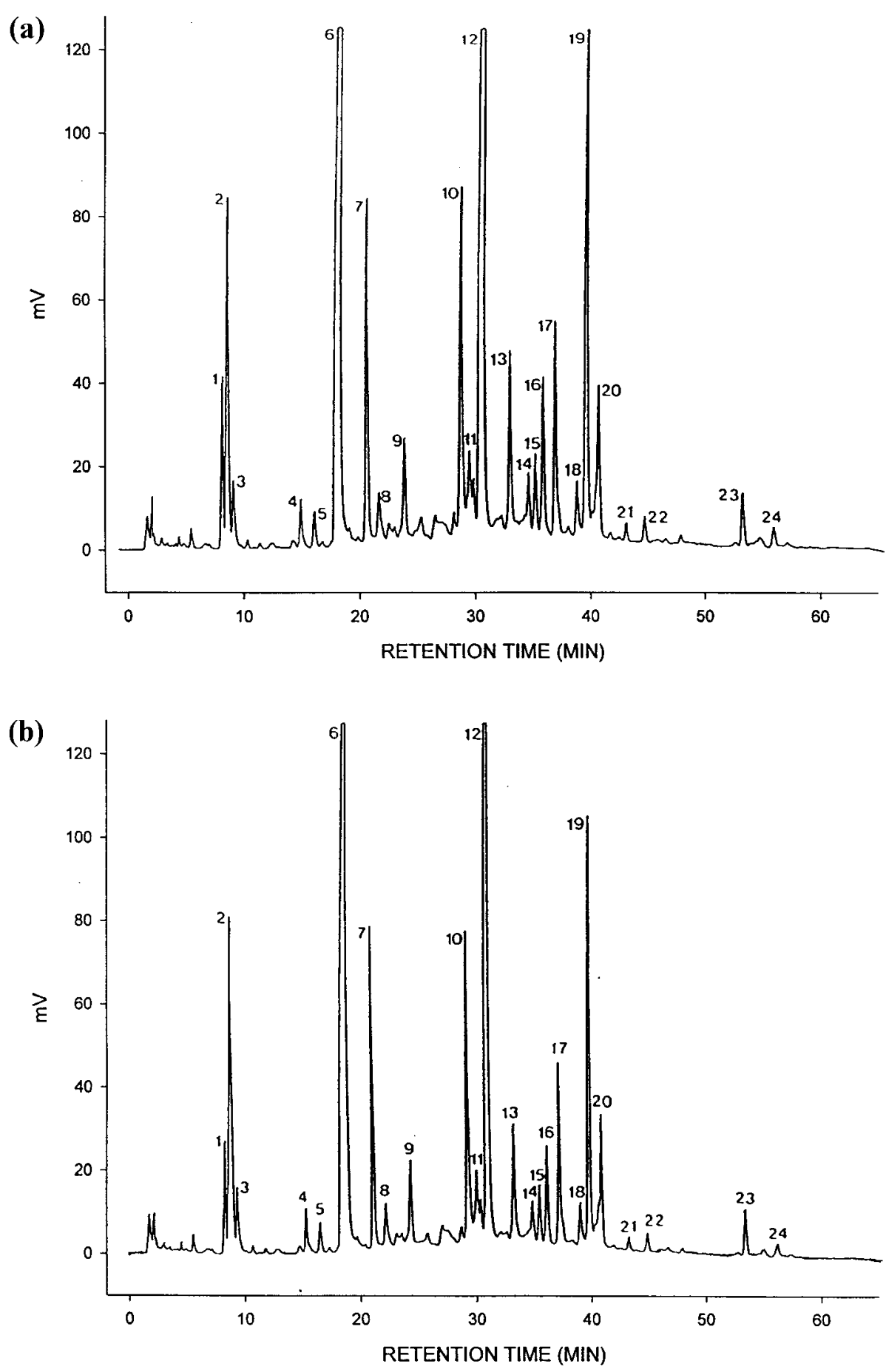

infusion participated in cream formation. Smith ${ }^{1}$ found that both potassium and calcium existed in black tea cream. Guo and Cheng ${ }^{22}$ reported that calcium ions were more easily precipitated with polyphenols than were other cations in tea infusions. Jackson and Lee ${ }^{23}$ stated that the insolubility of the calcium-polyphenols complex in tea was dependent upon the degree of enzymic oxidation in the fermentation process. Some research suggested that demineralisation could reduce cream formation in black tea. ${ }^{24}$ However, we found that the amounts of tea cream in Paochung tea infusions extracted with tap and deionised water were not significantly different (data not shown).

\section{Effect of tea leaf/water ratio}

The effect of the tea leaf/water ratio upon cream formation is shown in Table 3. An increase in the tea leaf/water ratio from 1.25 to $15 \%$ raised the total solids, caffeine, catechins, protein and pectin contents in the infusion. Although the amount of tea cream formed also increased with increasing leaf/water ratio, the percentage of each component in the tea cream was essentially the same. No cream formation was 


\begin{tabular}{|c|c|c|c|c|c|}
\hline \multirow[t]{2}{*}{ Peak } & \multirow[t]{2}{*}{ Compound } & \multicolumn{2}{|c|}{ Peak area ${ }^{a}$} & \multicolumn{2}{|c|}{ Difference } \\
\hline & & Original & Clarified & Area & $\%$ \\
\hline 1 & & $421737^{a}$ & $302223^{b}$ & 119514 & 28.3 \\
\hline 2 & Theobromine & $1024565^{a}$ & $1032461^{a}$ & & \\
\hline 3 & Gallic acid & $268766^{a}$ & $273675^{a}$ & & \\
\hline 4 & & $209110^{a}$ & $191682^{a}$ & & \\
\hline 5 & & $150507^{a}$ & $137664^{a}$ & & \\
\hline 6 & Caffeine & $11958209^{a}$ & $8090541^{b}$ & 3867668 & 32.3 \\
\hline 7 & $(-)$-EGC & $1316670^{a}$ & $1239087^{a}$ & & \\
\hline 8 & $(+)-C$ & $327905^{a}$ & $312290^{a}$ & & \\
\hline 9 & & $609212^{a}$ & $541585^{a}$ & & \\
\hline 10 & $(-)-E C$ & $1492750^{\mathrm{a}}$ & $1402111^{a}$ & & \\
\hline 11 & & $427212^{a}$ & $400249^{a}$ & & \\
\hline 12 & $(-)-E G C G$ & $10640832^{a}$ & $7832818^{b}$ & 2808013 & 26.4 \\
\hline 13 & & $868662^{a}$ & $636434^{b}$ & 232228 & 26.7 \\
\hline 14 & & $329649^{a}$ & $242614^{b}$ & 87035 & 26.4 \\
\hline 15 & & $383010^{a}$ & $268890^{\mathrm{b}}$ & 114120 & 29.8 \\
\hline 16 & & $755976^{a}$ & $519101^{\mathrm{b}}$ & 236876 & 31.3 \\
\hline 17 & & $958895^{a}$ & $887028^{b}$ & 71867 & 7.5 \\
\hline 18 & Rutin & $327111^{a}$ & $256750^{b}$ & 70361 & 21.5 \\
\hline 19 & $(-)-E C G$ & $2367695^{a}$ & $1824376^{b}$ & 543320 & 23.0 \\
\hline 20 & & $817665^{a}$ & $708773^{b}$ & 108892 & 13.3 \\
\hline 21 & & $101762^{a}$ & $60325^{b}$ & 41437 & 40.7 \\
\hline 22 & & $133167^{a}$ & $85078^{b}$ & 48089 & 36.1 \\
\hline 23 & & $214500^{a}$ & $182075^{b}$ & 32425 & 15.1 \\
\hline 24 & Quercetin & $91517^{a}$ & $68587^{\mathrm{b}}$ & 22930 & 25.1 \\
\hline
\end{tabular}

2. Comparison of peak areas of polyphenols and caffeine in Paochung tea infusion before and

${ }^{a}$ Means $(n=4)$ in the same row superscripted with different letters are significantly different $(p<0.05)$

Table 3. Effect of tea leaf/water ratio (TW) on total solids, amount of cream formation and concentrations of caffeine, catechins, protein and pectin in Paochung tea infusion and their percentages in tea cream ${ }^{\mathrm{a}}$

\begin{tabular}{|c|c|c|c|c|c|c|c|c|c|c|}
\hline $\begin{array}{l}\text { TW } \\
\text { (\%) }\end{array}$ & $\begin{array}{c}\text { Total solids } \\
(\mathrm{g} / 100 \mathrm{ml})\end{array}$ & $\begin{array}{c}\text { Tea } \\
\text { cream } \\
(\%)^{\mathrm{b}}\end{array}$ & $\begin{array}{c}\text { Caffeine in } \\
\text { tea infusion } \\
(\mathrm{g} / 100 \mathrm{ml})\end{array}$ & $\begin{array}{c}\text { Caffeine } \\
\text { in tea } \\
\text { cream } \\
(\%)^{c}\end{array}$ & $\begin{array}{l}\text { Catechins } \\
\text { in tea } \\
\text { infusion } \\
\text { (g/100ml) }\end{array}$ & $\begin{array}{c}\text { Catechins } \\
\text { in tea } \\
\text { cream } \\
(\%)^{\mathrm{c}}\end{array}$ & $\begin{array}{l}\text { Protein in } \\
\text { tea infusion } \\
(\mathrm{g} / 100 \mathrm{ml})\end{array}$ & $\begin{array}{c}\text { Protein in } \\
\text { tea cream } \\
(\%)^{c}\end{array}$ & $\begin{array}{l}\text { Pectin in } \\
\text { tea infusion } \\
(\mathrm{g} / 100 \mathrm{ml})\end{array}$ & $\begin{array}{c}\text { Pectin in } \\
\text { tea cream } \\
(\%)^{\mathrm{c}}\end{array}$ \\
\hline 1.25 & $0.47^{\mathrm{h}}$ & NS & - & - & - & - & - & - & - & - \\
\hline 2 & $0.74^{\mathrm{g}}$ & NS & - & - & - & - & - & - & - & - \\
\hline 2.5 & $0.88^{f}$ & $6.8^{\mathrm{e}}$ & $N D$ & ND & $N D$ & ND & $N D$ & ND & $N D$ & ND \\
\hline 5 & $1.97^{\mathrm{e}}$ & $9.1^{\mathrm{c}}$ & $0.22^{\mathrm{e}}$ & $25.3^{a}$ & $0.76^{\mathrm{e}}$ & $31.1^{\mathrm{a}}$ & $0.05^{\mathrm{e}}$ & $19.4^{a}$ & $0.05^{e}$ & $2.6^{a}$ \\
\hline 8 & $3.11^{d}$ & $14.5^{\mathrm{b}}$ & $0.33^{d}$ & $18.7^{\mathrm{a}}$ & $1.24^{\mathrm{d}}$ & $25.8^{a}$ & $0.11^{d}$ & $17.0^{\mathrm{a}}$ & $0.08^{d}$ & $2.0^{\mathrm{a}}$ \\
\hline 10 & $3.84^{c}$ & $14.1^{b}$ & $0.38^{c}$ & $15.6^{a}$ & $1.50^{c}$ & $30.6^{a}$ & $0.14^{\mathrm{C}}$ & $16.0^{\mathrm{a}}$ & $0.10^{c}$ & $1.3^{\mathrm{a}}$ \\
\hline 12.5 & $4.69^{b}$ & $17.3^{a}$ & $0.50^{\mathrm{b}}$ & $18.2^{a}$ & $1.79^{b}$ & $30.6^{a}$ & $0.21^{b}$ & $16.9^{a}$ & $0.13^{b}$ & $1.5^{\mathrm{a}}$ \\
\hline 15 & $5.47^{a}$ & $16.5^{\mathrm{a}}$ & $0.58^{a}$ & $21.8^{a}$ & $2.14^{\mathrm{a}}$ & $34.9^{a}$ & $0.25^{a}$ & $17.8^{\mathrm{a}}$ & $0.14^{a}$ & $2.6^{\mathrm{a}}$ \\
\hline
\end{tabular}

${ }^{a}$ The tea infusions were extracted at $90^{\circ} \mathrm{C}$ for $20 \mathrm{~min}$. The mean values $(n=4)$ in each column with the same superscript letters are not significantly different at the $5 \%$ level using Duncan's multiple-range test. NS represents no cream formation. ND means the constituents were not determined.

b Percentage of total solids of tea infusion.

${ }^{\mathrm{c}}$ Percentage of tea cream by weight.

observed when the leaf/water ratio was $2 \%$ or lower, indicating that a minimum concentration was required to produce tea cream.

\section{Effect of extraction temperature}

The effect of the extraction temperature upon cream formation in Paochung tea was investigated by extracting the tea with a $12.5 \%$ leaf/water ratio at 30 , 50,70 and $90^{\circ} \mathrm{C}$ for $20 \mathrm{~min}$. As shown in Table 4, the total solids content and the amount of cream increased with increasing extraction temperature. The composi- tion of the tea cream was also affected by the extraction temperature. The caffeine content remained constant. Rutter and Stainsby ${ }^{3}$ also reported that the caffeine content in black tea cream was maintained at $25-27 \%$ under various extraction conditions.

The content of catechins in the cream increased with increasing extraction temperature, while the contents of protein and pectin decreased. It was noted that there was a significant amount of tea cream in Paochung tea extracted at temperatures as low as $30^{\circ} \mathrm{C}$, but a black tea infusion extracted at $30^{\circ} \mathrm{C}$ did 
Table 4. Effect of extraction temperature on total solids, amount of cream formation and concentrations of caffeine, catechins, protein and pectin in Paochung tea infusion and their percentages in tea cream ${ }^{a}$

\begin{tabular}{|c|c|c|c|c|c|c|c|c|c|c|}
\hline $\begin{array}{l}\text { Extraction } \\
\text { temp }\left({ }^{\circ} \mathrm{C}\right)\end{array}$ & $\begin{array}{c}\text { Total solids } \\
(\mathrm{g} / 100 \mathrm{ml})\end{array}$ & $\begin{array}{c}\text { Tea } \\
\text { cream } \\
(\%)^{b}\end{array}$ & $\begin{array}{c}\text { Caffeine in } \\
\text { tea infusion } \\
(\mathrm{g} / 100 \mathrm{ml})\end{array}$ & $\begin{array}{l}\text { Caffeine } \\
\text { in tea } \\
\text { cream } \\
(\%)^{\mathrm{c}}\end{array}$ & $\begin{array}{c}\text { Catechins } \\
\text { in tea } \\
\text { infusion } \\
(\mathrm{g} / 100 \mathrm{ml})\end{array}$ & $\begin{array}{c}\text { Catechins } \\
\text { in tea } \\
\text { cream } \\
(\%)^{\mathrm{c}}\end{array}$ & $\begin{array}{c}\text { Protein in } \\
\text { tea infusion } \\
(\mathrm{g} / 100 \mathrm{ml})\end{array}$ & $\begin{array}{c}\text { Protein in } \\
\text { tea cream } \\
(\%)^{\mathrm{c}}\end{array}$ & $\begin{array}{c}\text { Pectin in } \\
\text { tea infusion } \\
(\mathrm{g} / 100 \mathrm{ml})\end{array}$ & $\begin{array}{c}\text { Pectin in } \\
\text { tea cream } \\
(\%)^{c}\end{array}$ \\
\hline 30 & $3.37^{d}$ & $6.2^{d}$ & $0.36^{b}$ & $17.2^{\mathrm{a}}$ & $1.30^{d}$ & $12.4^{\mathrm{C}}$ & $0.10^{d}$ & $34.0^{\mathrm{a}}$ & $0.04^{c}$ & $9.1^{\mathrm{a}}$ \\
\hline 50 & $4.04^{c}$ & $11.4^{\mathrm{C}}$ & $0.39^{b}$ & $14.3^{a}$ & $1.48^{\mathrm{C}}$ & $23.3^{b}$ & $0.15^{c}$ & $22.2^{b}$ & $0.06^{b}$ & $3.0^{b}$ \\
\hline 70 & $4.24^{b}$ & $14.6^{b}$ & $0.46^{\mathrm{a}}$ & $17.3^{a}$ & $1.63^{b}$ & $26.6^{b}$ & $0.18^{b}$ & $21.3^{b}$ & $0.06^{b}$ & $2.4^{b}$ \\
\hline 90 & $4.73^{a}$ & $17.8^{a}$ & $0.48^{a}$ & $18.3^{a}$ & $1.79^{a}$ & $30.6^{a}$ & $0.21^{a}$ & $19.0^{b}$ & $0.13^{a}$ & $1.5^{b}$ \\
\hline
\end{tabular}

a The tea infusions were extracted with a $12.5 \%$ tea leaf/water ratio for $20 \mathrm{~min}$. The mean values $(n=4)$ in each column with the same superscript letters are not significantly different at the $5 \%$ level using Duncan's multiple-range test.

b Percentage of total solids of tea infusion.

${ }^{c}$ Percentage of tea cream by weight.

Table 5. Effect of extraction time on total solids, amount of cream formation and concentrations of caffeine, catechins, protein and pectin in Paochung tea infusion and their percentages in tea cream ${ }^{\mathrm{a}}$

\begin{tabular}{|c|c|c|c|c|c|c|c|c|c|c|}
\hline $\begin{array}{l}\text { Extraction } \\
\text { time (min) }\end{array}$ & $\begin{array}{c}\text { Total solids } \\
(\mathrm{g} / 100 \mathrm{ml})\end{array}$ & $\begin{array}{c}\text { Tea } \\
\text { cream } \\
(\%)^{\mathrm{b}}\end{array}$ & $\begin{array}{c}\text { Caffeine in } \\
\text { tea infusion } \\
(\mathrm{g} / 100 \mathrm{ml})\end{array}$ & $\begin{array}{c}\text { Caffeine } \\
\text { in tea } \\
\text { cream } \\
(\%)^{\mathrm{c}}\end{array}$ & $\begin{array}{l}\text { Catechins } \\
\text { in tea } \\
\text { infusion } \\
(\mathrm{g} / 100 \mathrm{ml})\end{array}$ & $\begin{array}{c}\text { Catechins } \\
\text { in tea } \\
\text { cream } \\
(\%)^{\mathrm{C}}\end{array}$ & $\begin{array}{l}\text { Protein in } \\
\text { tea infusion } \\
(\mathrm{g} / 100 \mathrm{ml})\end{array}$ & $\begin{array}{c}\text { Protein in } \\
\text { tea cream } \\
(\%)^{c}\end{array}$ & $\begin{array}{l}\text { Pectin in } \\
\text { tea infusion } \\
(\mathrm{g} / 100 \mathrm{ml})\end{array}$ & $\begin{array}{c}\text { Pectin in } \\
\text { tea cream } \\
(\%)^{c}\end{array}$ \\
\hline 5 & $4.30^{\mathrm{C}}$ & $16.5^{\mathrm{a}}$ & $0.48^{a}$ & $23.1^{\mathrm{a}}$ & $1.80^{\mathrm{C}}$ & $14.0^{b}$ & $0.18^{b}$ & $17.3^{a}$ & $0.07^{c}$ & $1.9^{\mathrm{a}}$ \\
\hline 10 & $4.40^{b}$ & $16.8^{a}$ & $0.44^{a}$ & $20.0^{\mathrm{a}}$ & $1.91^{b}$ & $25.3^{a}$ & $0.20^{b}$ & $20.2^{a}$ & $0.09^{c}$ & $1.6^{\mathrm{a}}$ \\
\hline 20 & $4.82^{a}$ & $17.4^{\mathrm{a}}$ & $0.48^{a}$ & $18.3^{a}$ & $2.08^{a}$ & $31.2^{\mathrm{a}}$ & $0.24^{a}$ & $18.8^{a}$ & $0.14^{b}$ & $1.5^{\mathrm{a}}$ \\
\hline 60 & $4.88^{a}$ & $16.4^{a}$ & $0.47^{a}$ & $16.0^{a}$ & $2.07^{a}$ & $34.2^{\mathrm{a}}$ & $0.25^{\mathrm{a}}$ & $19.7^{a}$ & $0.20^{\mathrm{a}}$ & $1.8^{\mathrm{a}}$ \\
\hline
\end{tabular}

${ }^{a}$ The tea infusions were extracted with a $12.5 \%$ tea leaf/water ratio at $90^{\circ} \mathrm{C}$. The mean values $(n=4)$ in each column with the same superscript letters are not significantly different at the $5 \%$ level using Duncan's multiple-range test.

b Percentage of total solids of tea infusion.

${ }^{c}$ Percentage of tea cream by weight.

not form cream. ${ }^{3}$ The difference in creaming behaviour between Paochung tea and black tea was probably due to most of the polyphenols in black tea existing in their oxidised forms, having a higher degree of polymerisation and being unable to be extracted efficiently at low temperatures, whereas most of the polyphenols in Paochung tea have their simple structures unchanged and thus can be extracted at $30^{\circ} \mathrm{C}$.

\section{Effect of extraction time}

Table 5 shows the effect of the extraction time upon cream formation in Paochung tea at $90^{\circ} \mathrm{C}$. The total solids in the infusion increased significantly $(p<0.05)$ with increasing extraction time from 5 to $20 \mathrm{~min}$, but a further increase in extraction time to $60 \mathrm{~min}$ did not significantly change the total solids content. An increase in the extraction time from 5 to $20 \mathrm{~min}$ increased the catechins and protein contents in the infusion. Increasing the extraction time further did not increase their extractability either. Therefore extraction at $90^{\circ} \mathrm{C}$ for $20 \mathrm{~min}$ was considered to be long enough to extract most of the major components that contribute to cream formation. Since the amount of the tea cream was not affected by the length of extraction time, a reduction in the extraction time even down to $5 \mathrm{~min}$ would not reduce cream formation in Paochung tea.

\section{Effect of $\mathrm{pH}$}

The $\mathrm{pH}$ of the infusion affected the total solids content in the tea infusion, the amount of tea cream formation and the composition of the cream (Table 6). The total solids content had the lowest value at $\mathrm{pH} 5.5$ (the $\mathrm{pH}$ value of the original tea infusion) owing to the low extraction rates of catechins and proteins at this $\mathrm{pH}$. At low pHs (3.22 and 4.20) the catechins content in the tea infusion, as well as in the cream, was significantly higher than that at higher pHs (5.50 and 6.86). The protein content too was significantly higher, but only at the lowest $\mathrm{pH}$, seeming to increase again at the highest $\mathrm{pH}$. The polyphenols are believed to bind proteins primarily through the formation of multiple hydrogen bonds between their phenolic groups and the carbonyl functions of the peptide linkages. ${ }^{25}$ The tea proteins are likely to have $\mathrm{p} I$ values close to $\mathrm{pH}$ 3.2-4.2, where protein-protein electrostatic repulsion would be minimised and result in maximum cream formation. However, the $\mathrm{pH}$ did not affect the caffeine content of the tea infusion or the percentage of caffeine in the cream. Spiro and Price ${ }^{26,27}$ also reported that the $\mathrm{pH}$ did not affect the extractability of caffeine in black tea.

Although the amount of cream formed at $\mathrm{pH} 3.22$ and 4.20 was higher than that at $\mathrm{pH} 5.50$ and 6.86 , the extent of the difference in cream formation due to the difference in the $\mathrm{pH}$ of the Paochung tea infusion was 
Table 6. Effects of $\mathrm{pH}$ of Paochung tea infusion on total solids, tea cream formation and concentrations of caffeine, catechins, protein and pectin and their percentages in tea cream $^{\mathrm{a}}$

\begin{tabular}{|c|c|c|c|c|c|c|c|c|c|c|}
\hline$p H$ & $\begin{array}{c}\text { Total solids } \\
(\mathrm{g} / 100 \mathrm{ml})\end{array}$ & $\begin{array}{c}\text { Tea } \\
\text { cream } \\
(\%)^{b}\end{array}$ & $\begin{array}{c}\text { Caffeine in } \\
\text { tea infusion } \\
(\mathrm{g} / 100 \mathrm{ml})\end{array}$ & $\begin{array}{c}\text { Caffeine in } \\
\text { tea cream } \\
(\%)^{\mathrm{c}}\end{array}$ & $\begin{array}{c}\text { Catechins in } \\
\text { tea infusion } \\
(\mathrm{g} / 100 \mathrm{ml})\end{array}$ & $\begin{array}{c}\text { Catechins } \\
\text { in tea } \\
\text { cream }(\%)^{\mathrm{c}}\end{array}$ & $\begin{array}{c}\text { Protein in } \\
\text { tea infusion } \\
(\mathrm{g} / 100 \mathrm{ml})\end{array}$ & $\begin{array}{c}\text { Protein in } \\
\text { tea cream } \\
(\%)^{\mathrm{c}}\end{array}$ & $\begin{array}{c}\text { Pectin in } \\
\text { tea infusion } \\
(\mathrm{g} / 100 \mathrm{ml})\end{array}$ & $\begin{array}{c}\text { Pectin in } \\
\text { tea cream } \\
(\%)^{c}\end{array}$ \\
\hline 3.22 & $4.20^{a}$ & $16.1^{a}$ & $0.39^{a}$ & $22.0^{a}$ & $1.61^{a}$ & $36.8^{a}$ & $0.34^{a}$ & $33.8^{a}$ & ND & ND \\
\hline 4.20 & $3.86^{c}$ & $15.9^{a}$ & $0.40^{a}$ & $24.5^{a}$ & $1.69^{a}$ & $37.7^{\mathrm{a}}$ & $0.22^{b}$ & $21.3^{b c}$ & ND & ND \\
\hline 5.50 & $3.79^{c}$ & $14.3^{b}$ & $0.40^{a}$ & $18.5^{a}$ & $1.51^{b}$ & $30.0^{b}$ & $0.14^{c}$ & $18.5^{\mathrm{C}}$ & ND & ND \\
\hline 6.86 & $3.98^{b}$ & $12.9^{c}$ & $0.41^{a}$ & $19.6^{a}$ & $1.42^{\mathrm{C}}$ & $30.0^{b}$ & $0.20^{b}$ & $27.5^{\mathrm{b}}$ & ND & ND \\
\hline
\end{tabular}

a The tea infusions were extracted with a $10 \%$ tea leaf/water ratio at $90^{\circ} \mathrm{C}$ for $20 \mathrm{~min}$. Pectin was not determined (ND) in this experiment. The mean values $(n=4)$ in each column with the same superscript letters are not significantly different at the $5 \%$ level using Duncan's multiple-range test.

${ }^{b}$ Percentage of total solids of tea infusion.

${ }^{\mathrm{C}}$ Percentage of tea cream by weight.

much less than that in black tea. The maximum amount of tea cream in black tea was formed at $\mathrm{pH} 3$ $4,{ }^{1}$ while no cream formation was observed at $\mathrm{pH} 6.7$. It was also noted that raising the $\mathrm{pH}$ of the infusion significantly altered the colour and flavour of Paochung tea (data not shown). Suematsu et $a l^{28}$ stated that catechins were more unstable and became subject to greater oxidation in the high $\mathrm{pH}$ range during processing. Therefore adjusting the $\mathrm{pH}$ of the infusion may not be a feasible process for inhibiting the formation of cream in Paochung tea.

\section{CONCLUSION}

The formation of tea cream is still a significant problem in the application of Paochung tea as a cool drink, primarily because it causes an unattractive appearance and processing difficulties. The amount of cream in the tea and its composition were influenced by extraction temperature and $\mathrm{pH}$. The tea leaf/water ratio was found to affect the amount of cream in the infusion but not the cream composition. The polyphenolic compounds are probably the most important components in the formation of tea cream. They form a complex with caffeine and protein to create cream. Reducing the extraction temperature and adjusting the $\mathrm{pH}$ reduces cream formation, but inhibition of the development of Paochung tea cream without impairing the important sensory qualities or food safety remains a challenge in the processing of this tea.

\section{ACKNOWLEDGEMENTS}

This research was supported by the Council of Agriculture, ROC under project 83-2.8-08(9).

\section{REFERENCES}

1 Smith RF, Studies on the formation and composition of cream in tea infusion. F Sci Food Agric 19:530-534 (1968).

2 Collier PD, Mallows R and Thomas PE, Interactions between theaflavins, flavanols and caffeine. Phytochemistry 11:867 (1972).

3 Rutter P and Stainsby G, The solubility of tea cream. I Sci Food Agric 26:455-463 (1975).

4 Nagalakshimi $S$ and Seshadri R, A study of nitrogenous constituents of tea cream. F Food Sci Technol 20:243-245 (1983).

5 Powell C, Clifford MN, Opie SC, Ford MA, Robertson A and Gibson CL, Tea cream formation: the contribution of black tea phenolic pigments determined by HPLC. I Sci Food Agric 63:77-86 (1992).

6 Roberts EAH, The phenolic substances of manufactured tea. X. The creaming down of tea liquors. F Sci Food Agric 14:700-705 (1963).

7 Hazarika M, Chakravarty $\mathrm{SH}$ and Mahanta PK, Studies on thearubigins pigments in black tea manufacturing systems. $\mathcal{F}$ Sci Food Agric 35:1208-1218 (1984).

8 Seshadri R and Nagalakshimi D, New hydrophobic lipid interaction in tea cream. F Sci Food Agric 45:79-86 (1988).

9 AOAC, Official Methods of Analysis, 14th edn, Association of Official Analytical Chemists, Washington, DC (1984).

10 Tasi YZ and Juan IM, A simple determination method of caffeine in tea. Taiwan Tea Res Bull 6:1-7 (1987).

11 Sarker SK and Howarth RE, Specificity of the vanillin test for flavanols. F Agric Food Chem 24:317-320 (1976).

12 Terada S, Maeda Y, Masui T, Suzuki Y and Ina K, Comparison of caffeine and catechin components in infusion of various tea (Green, Oolong and Black tea) and tea drinks. Nippon Shikuhin Kogyo Gakkaishi 34:20-27 (1987).

13 Lowry OH, Rosebrough NJ, Farr AL and Randall RJ, Protein measurement with Folin phenol reagent. F Biol Chem 193:265275 (1951).

14 Blumenkrantz $\mathrm{N}$ and Asoboe-Hansen G, New method for quantitative determination of uronic acids. Anal Biochem 54:484490 (1973).

15 McManus JP, Davis K, Haslam E and Lilley TH, The association of proteins with phenols. $\mathcal{F}$ Chem Soc, Chem Commun 309-311 (1981).

16 Martin R, Lilley TH, Bailey NA, Falshaw CP, Haslam E, Magnolato D and Begley MJ, Polyphenols-caffeine complexation. 7 Chem Soc, Chem Commun 105-106 (1986).

17 Gaffney SH, Martin R, Lilley TH, Haslam E and Magnolato D, The association of polyphenols with caffeine and $\alpha$ - and $\beta$ cyclodextrin in aqueous media. $\mathcal{F}$ Chem Soc, Chem Commun 107-109 (1986).

18 Mejbaum-Katzenellenbogen W, Dobryszychka WM, Jaworska K and Wiecka BM, Regeneration of protein from insoluble protein-tannin compounds. Nature (London) 184:1799-1800 (1959).

19 Bailey RG, Nursten HE and McDowell I, Comparative study of the reversed-phase high-performance liquid chromatography of black tea liquors with special reference to the thearubigins. $\mathcal{F}$ Chromatogr 542:115-128 (1991).

20 Sekiya J, Kadahiko K, Monma T and Hatanaka A, Interaction of tea catechins with proteins: formation of protein precipitate. Agric Biol Chem 48:1963-1967 (1984).

21 Millin DJ, Swain D and Dix PL, Separation and classification of 
aqueous infused brown pigments of black tea. 7 Sci Food Agric 20:296-302 (1969).

22 Guo BY and Cheng QK, Reaction of tea infusion components with metal ions and its application to preparation of pure polyphenols. Proc Int Symp on Tea Science, pp 86-88 (1991).

23 Jackson LS and Lee K, Chemical forms of iron, calcium, magnesium and zinc in black, Oolong, green and instant black tea. F Food Sci 50:181-184 (1988).

24 Pintauro ND, Tea and Soluble Tea Products Manufacture, Noyes Data Co, Park Ridge, NJ, pp 82-125 (1977).

25 Van Sumere CF, Albrecht J, Dedonder A, De Pooter H and Pe I. Plant Proteins and Phenolics, In The Chemistry and Biochemistry of Plant Proteins, Ch 8, Ed by Harborne JB and Van Sumere CF, Academic Press, New York, pp 211-264 (1975).
26 Spiro $M$ and Price $W$, Kinetics and equilibria of tea infusionPart 6: The effects of salts and $\mathrm{pH}$ on the concentrations and partition constants of theaflavins and caffeine in Kapchorua Pekoe Fannings. Food Chem 24:51-61 (1987).

27 Spiro $M$ and Price W, Kinetics and equilibria of tea infusionPart 7: The effects of salts and $\mathrm{pH}$ on the rate of extraction of caffeine in Kapchorua Pekoe Fannings. Food Chem 25:49-59 (1987).

28 Suematsu S, Hisanobu Y, Saigo H, Musuda R, Hara K and Komatsu Y, Effects of $\mathrm{pH}$ on stability of constituents in canned tea drinks. Nippon Shakuhin Kogyo Gakkaishi 39:178-182 (1992). 